\title{
SMART - Sediment Mitigation Actions for the River Rother, UK
}

\author{
Jennine L. Evans ${ }^{1}$, Ian Foster ${ }^{1,2}$, John Boardman ${ }^{3,4}$, and Naomi Holmes ${ }^{5}$ \\ ${ }^{1}$ Department of Environmental and Geographical Sciences, University of Northampton, \\ Northampton, NN2 6JB, UK \\ ${ }^{2}$ Geography Department, Rhodes University, Grahamstown 6140, Eastern Cape, South Africa \\ ${ }^{3}$ Environmental Change Institute, University of Oxford, Oxford, OX1 3QY, UK \\ ${ }^{4}$ Department of Environmental and Geographical Science, University of Cape Town, \\ Rondebosch 7701, South Africa \\ ${ }^{5}$ Department of the Natural and Built Environment, Sheffield Hallam University, Sheffield, S1 1WB, UK \\ Correspondence to: Jennine L. Evans (jennine.evans@ northampton.ac.uk)
}

Published: 3 March 2017

\begin{abstract}
The River Rother, West Sussex, is suffering from excess sediment which is smothering the river bed gravels. This is thought to be exacerbating issues of pollution and degradation of ecosystems. This project aims to identify the severity, extent, possible causes and potential mitigation options available to reduce these pressures on the river. Data have been collected from ten sites to investigate the amount of sediment stored in the river bed gravels and cores obtained from four small reservoirs to establish rates of sedimentation and contribute to the construction of a temporal sediment budget over the last 50-100 years. Evidence suggests that tributary streams have more stored sediment per $\mathrm{m}^{2}$ upstream of their confluence with the River Rother compared to the Rother itself. Reservoir core data indicate that sediment has accumulated more rapidly in the small reservoirs surrounded by mixed agricultural land compared to one surrounded by ancient woodland. These are preliminary results and work is continuing.
\end{abstract}

\section{Introduction}

In the UK, some rivers are failing to meet the criteria for achieving Good Ecological Status (GES) as set out in the European Union (EU) Water Framework Directive (WFD) (Defra, 2014; Official Journal of the European Communities, 2000). In many UK cases, including parts of the River Rother catchment, high sediment loads are the reason for failure to obtain GES (Environment Agency, 2016). Sear (1996) reported that the bed of the River Rother in West Sussex, UK had changed from one historically dominated by gravel, to one currently dominated by fine sand. While fine sand smothers the gravels there is an added issue of silt and clay transporting nutrients and pollutants into the river (Collins et al., 2009). These sediment pressures have been identified as key variables likely to prevent the attainment of GES in the Rother; the specific sources and causes of the problem have yet to be fully evaluated.
Excessive sediment in waterways causes negative direct impacts such as high turbidity and the siltation of river beds (Collins and Walling, 2007). High concentrations of sediment in the water column also have a number of indirect negative impacts on ecosystems, such as damaging fish gills and increasing eutrophication (Collins et al., 2010). Excessive sediment input is frequently caused by soil erosion on agricultural fields, although it has been suggested that channel banks can also be a major contributor (Pulley et al., 2015). The soil that erodes from fields can be delivered to waterways and roads where most negative impacts are felt (Boardman et al., 2003; Evans, 2010). This impacts society with financial costs to local authorities, the public and industries which depend on having a healthy river and good communication networks (Collins et al., 2010). Flood risk can be increased when soil erosion is increased. If soils are eroding into waterways it is usually due to an underlying issue with 


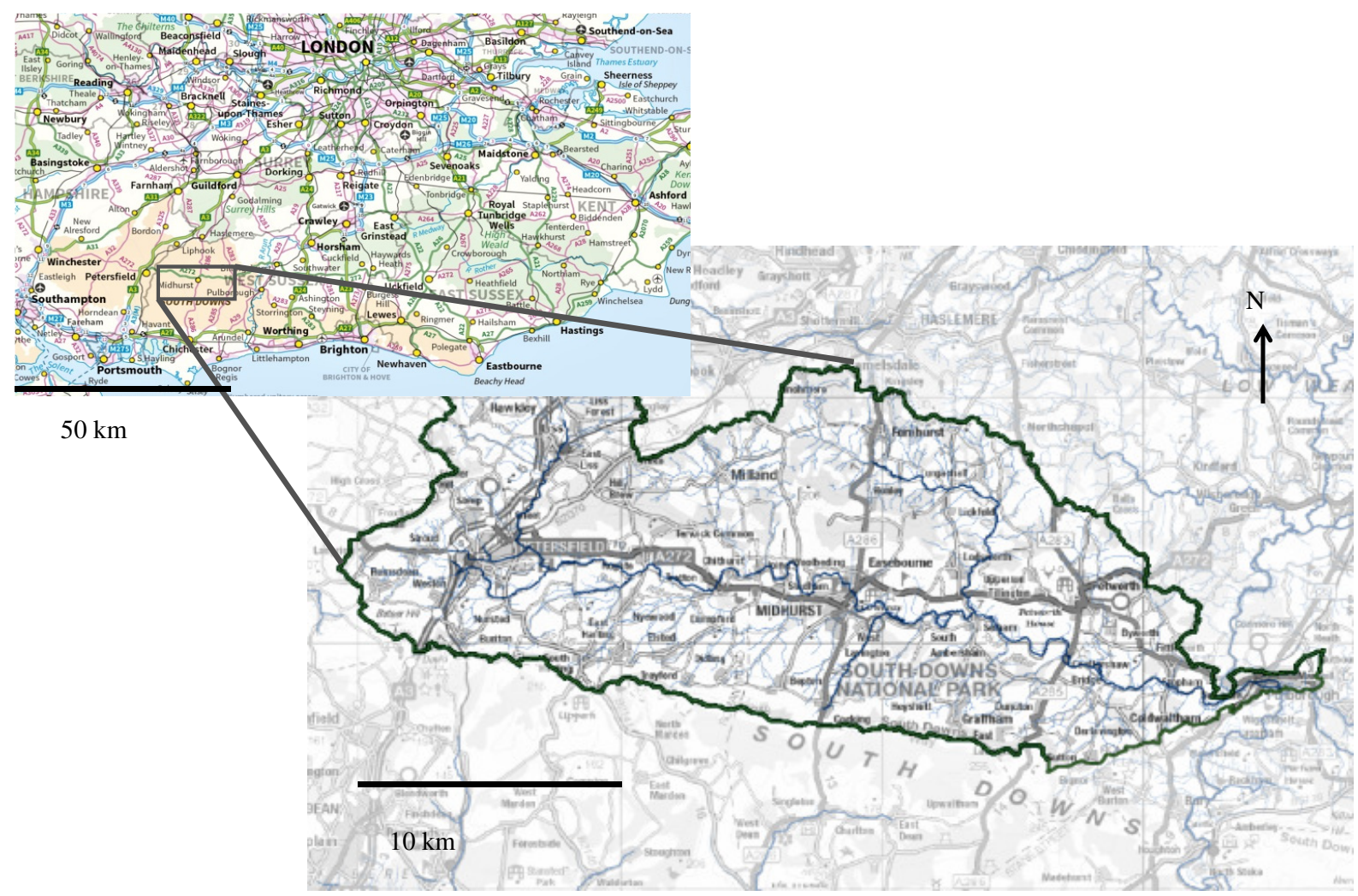

Figure 1. River Rother Catchment is located in the South Downs National Park with Midhurst at the centre (Edina Digimap, 2014; South Downs National Park Authority, 2015).

soil health. A reduced rate of water infiltration into the soil, or soil capping, increases the flashiness of surface runoff and increases sediment detachment and transport (Boardman and Favis-Mortlock, 2014). If the soil has a reduced infiltration capacity, excess water can create muddy flows that run across the land and into rivers, thereby increasing flood magnitude (Boardman and Favis-Mortlock, 2014).

\subsection{Catchment description}

The River Rother catchment is located in West Sussex/Hampshire in the South of England (Fig. 1). It drains $350 \mathrm{~km}^{2}$ and the river itself is $52 \mathrm{~km}$ in length. The catchment marks the northern limit of the South Downs National Park. The two main tributaries of the Rother are the Lod Stream and the Hammer Stream, both northern (left bank) tributaries (Figs. 1 and 2).

Geologically, the area is underlain by Chalk and Lower Greensand of Cretaceous age and part of the Wealden group. The sandy soils developed on Cretaceous Greensand are naturally at high risk of erosion as they lack the cohesive bonding that silt and clay can provide (Evans, 1990). There are 21 soil associations within the Rother catchment (Evans, 1990). Seven of these soil associations are at "moderate" and "high" risk of soil erosion (Table 1); these cover ca. $64 \%$ of the
Table 1. Soils at moderate (3) and high (4) risk of soil erosion within the Rother catchment (Evans, 1990).

\begin{tabular}{llc}
\hline Soil association No. & Soil association name & Erosion class \\
\hline $511 \mathrm{~g}$ & COOMBE 2 & 3 \\
$554 \mathrm{a}$ & FRILFORD & 4 \\
$571 \mathrm{~d}$ & FYFIELD 1 & 4 \\
$571 \mathrm{e}$ & FYFIELD 2 & 4 \\
$571 \mathrm{i}$ & HARWELL & 3 \\
$572 \mathrm{k}$ & BIGNOR & 3 \\
$631 \mathrm{~d}$ & SHIRRELL HEATH 2 & 3 \\
\hline
\end{tabular}

catchment. The topography is undulating with some locally steep areas and the altitude ranges from 0.4-250 m ODN. Average temperatures are between 6.2 and $15.1^{\circ} \mathrm{C}$ and annual average rainfall is $\sim 826 \mathrm{~mm}$ (Met Office, 2014).

Land use consists of arable land covering ca. $28 \%$ of the catchment area with crops of winter wheat, maize, salad vegetables, potatoes and turnips which are all high erosion risk crops (Boardman and Favis-Mortlock, 2014; South Downs National Park Authority, 2015). Prior to the 1950s, the catchment was predominantly under permanent grazing. The steeper slopes further from the River Rother are mostly under grazing (ca. 36\%) and woodland (ca. 30\%). There are 


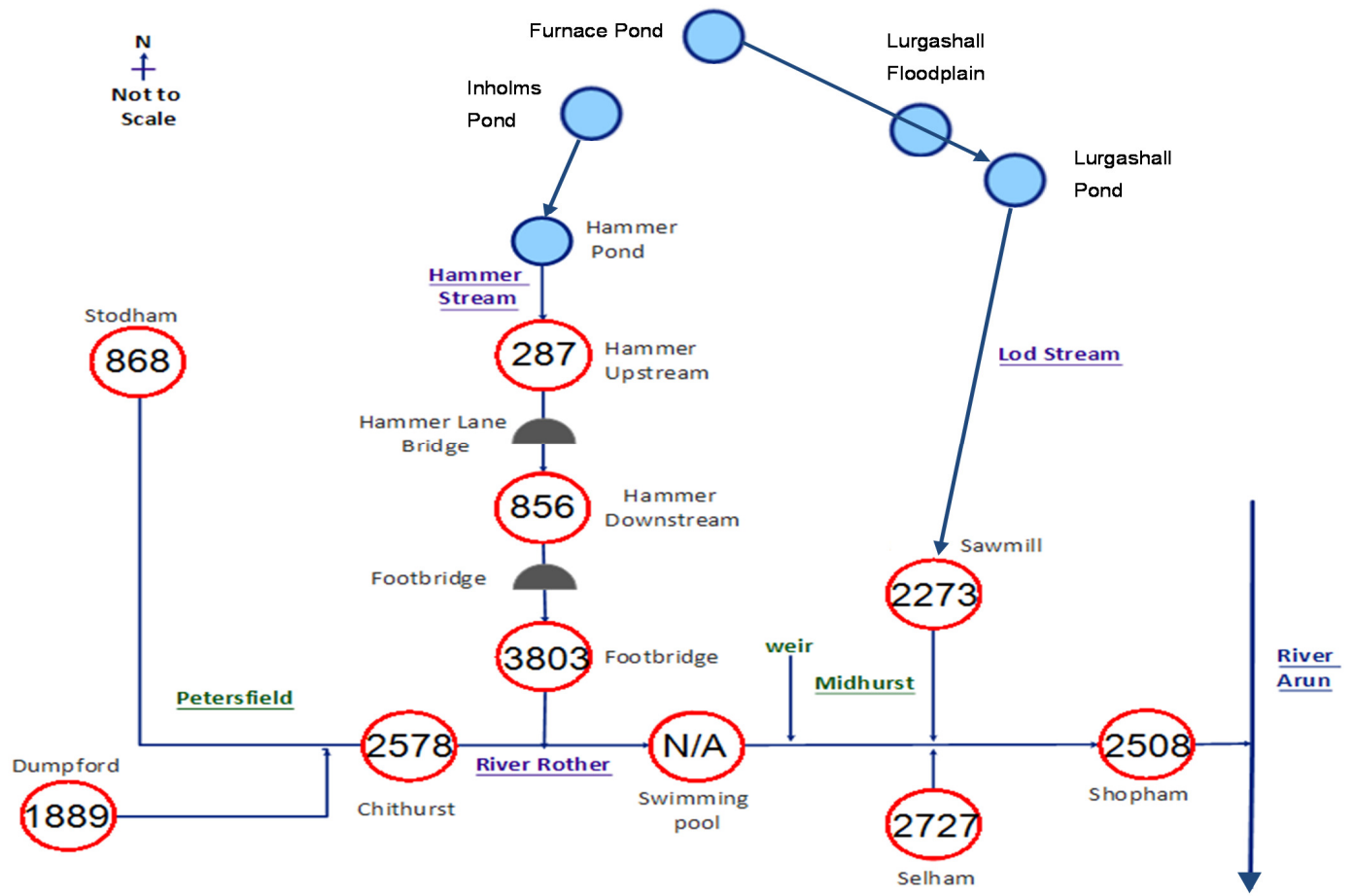

Figure 2. Locations of the monitoring sites in the Rother catchment (red circles) and coring sites (blue circles). Red circles display mean sediment storage at the monitoring sites $\left(\mathrm{g} \mathrm{m}^{-2}\right)$.

a number of small villages and towns (ca. $4 \%$ ) but no major urban centres (South Downs National Park Authority, 2015).

\subsection{Aims and objectives}

This project aims to identify the severity, extent, possible causes and potential mitigation options available to reduce sediment pressures on the River Rother.

The objectives are;

1. To identify potential sediment sources and pathways for runoff and sediment transfer into the river system.

2. To reconstruct partial sediment budgets in the catchment over the last ca. 100 years.

3. To evaluate a range of sediment mitigation options that might be employed to control sediment delivery to rivers from sources and pathways identified in objectives 1 and 2.

\section{Methods - river bed sediment sampling}

In order to investigate the potential sources of sediment being carried by the River Rother and stored in, or smothering the substrate gravels, ten monitoring/sampling stations were selected. Stations include four along the main stem of the Rother, four on the Lod and Hammer streams, and two on small unnamed right bank tributaries, at Dumpford and Selham (Fig. 1).

At each site, a $10 \mathrm{~L}$ time integrated tube sampler was installed to collect suspended sediment at two month intervals (Phillips et al., 2000). At all sites except one, a river bed disturbance technique was used to take samples of the fine sediment deposited in the gravels (Collins and Walling, 2007). These samples will be compared with characteristics of potential sediment sources.

\section{Coring}

Sediment deposited in reservoirs (which are man-made, some for Medieval iron works) and floodplains can provide historical data as sediment transported by the rivers and streams settles at the bottom of receptors or on floodplains after a flood event (Pittam et al., 2008; Walling et al., 2008). Furnace Pond, Hammer Pond, Lurgashall Mill Pond and Inholms Pond (Fig. 1) were cored using either a Mackereth or a Russian Corer (Foster et al., 1998). Cores obtained reached depths of between 80 and $210 \mathrm{~cm}$.

\section{Preliminary results - river bed storage}

Average bed sediment storage was estimated and results are shown in Fig. 2. In a study by Naden et al. (2016), the national range of stored sediment was found to lie between 6 and $4562 \mathrm{~g} \mathrm{~m}^{-2}$ (median $181 \mathrm{~g} \mathrm{~m}^{-2}$ ), with a similar range 
confirmed in an independent study in the UK by Collins and Walling (2007). It appears that all of the stored sediment estimates plotted in Fig. 2 are high compared with these studies, further suggesting that issues exist with stored sediment in this catchment irrespective of whether the sediment is also carrying any contaminants associated with it.

The site at Stodham has lower stored sediment compared to the rest of the monitoring sites indicating fewer sediment pressures in this headwater area, although sedimentassociated pollution may possibly be a problem and is being investigated further. Most tributaries immediately upstream of their confluence with the Rother have high levels of stored sediment compared to Stodham and to the Hammer Stream immediately downstream of the Hammer Pond (Fig. 2). The river bed immediately downstream of the Hammer Pond had low fine sediment storage but the amount trapped rapidly increased immediately downstream of the Hammer Lane road bridge and exceeded average storage values for the main Rother channel. With the exception of the Hammer Stream, most tributaries appear to have similar amounts of sediment stored in channel beds.

\subsection{Reservoir sediment coring}

The Hammer Pond receives inflows from a mixed agricultural sub-catchment with arable, grazing and some woodland. Over $80 \mathrm{~cm}$ of sediment has accumulated in the Hammer Pond and Furnace Pond since 1954 (Fig. 3a, b) and over $150 \mathrm{~cm}$ in Lurgashall Mill Pond (Fig. 3c). These are some of the highest rates of sedimentation reported in the UK (Rose et al., 2010).

Inholms Pond is also in the Hammer Stream subcatchment but is mostly forested with only a small area of permanent grazing land in the central area. Therefore, Inholms is being used as a reference catchment for comparison with other sites as it is relatively undisturbed. Sedimentation rates at Inholms Pond (Fig. 3d) are about half those of the Hammer and Furnace Ponds within the same time frame.

\subsection{Conclusions and future work}

This project is still in progress so conclusions are tentative. The river bed sediment storage data indicates that the Hammer Stream is accumulating more sediment per $\mathrm{m}^{2}$ than the Rother itself. However identifying sources of the sediment in tributaries is key to understanding the sediment transport processes and accumulation in the Rother. Sediment source sampling is still in progress and will be analysed with a sediment unmixing model to determine provenance of the sediment in the waterways (Pulley et al., 2015). Sediment properties that will be used in this model include; particle size, mineral magnetism, radionuclides and sediment geochemistry.

The core data indicates that sediment accumulation is much higher in small reservoirs which receive sediment from mixed agricultural land as opposed to one surrounded by for-
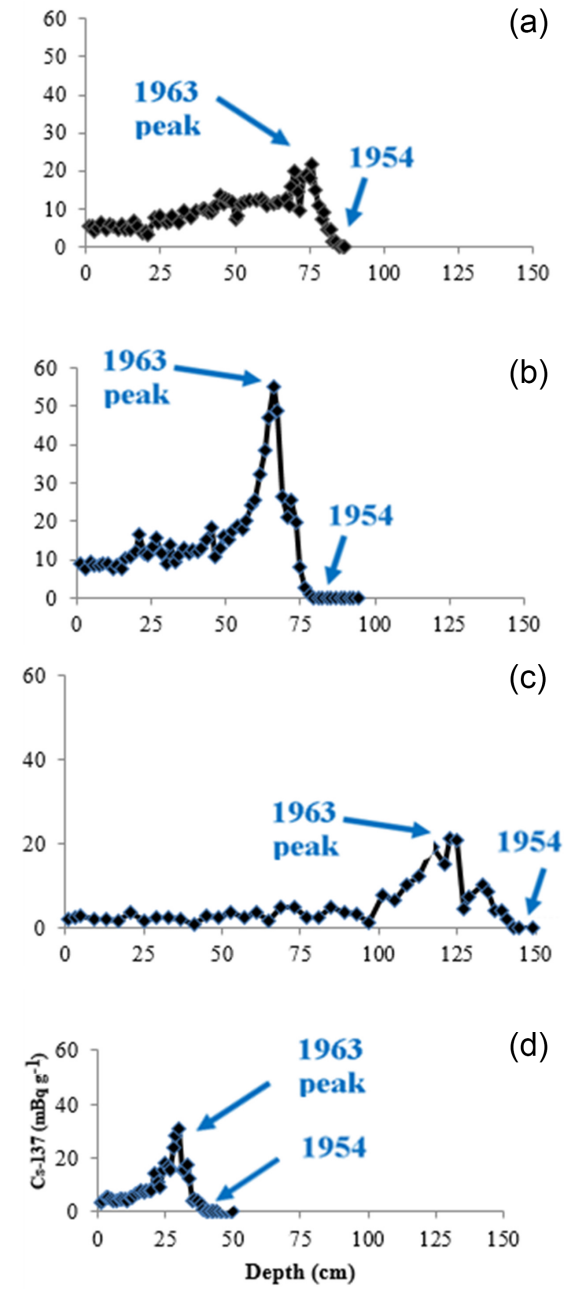

(d)

Figure 3. ${ }^{137}$ Cs profiles; (a), Furnace Pond; (b), Hammer Pond; (c), Lurgashall Mill Pond and (d), Inholms Pond.

est. The response of the floodplain upstream of Lurgashall Mill Pond is currently under investigation.

\section{Data availability}

The complete data set will be made public on the South Downs National Park (the funder) web site as an educational and research resource.

Competing interests. The authors declare that they have no conflict of interest.

Acknowledgements. We thank the South Downs National Park Authority (SDNPA) and the University of Northampton for funding the studentship associated with this project (JE) and the Arun and Rother Rivers Trust and Bruce Middleton (SDNPA) for helping secure site access and permissions to undertake this work. 


\section{References}

Boardman, J. and Favis-Mortlock, D. T.: The significance of drilling date and crop cover with reference to soil erosion by water, with implications for mitigating erosion on agricultural land in South East England, Soil Use Manage., 30, 40-47, doi:10.1111/sum.12095, 2014.

Boardman, J., Evans, R., and Ford, J.: Muddy floods on the South Downs, southern England: problem and responses, Environ. Sci. Policy, 6, 69-83, doi:10.1016/S1462-9011(02)00125-9, 2003.

Collins, A. L. and Walling, D. E.: Fine-grained bed sediment storage within the main channel systems of the Frome and Piddle catchments, Dorset, UK, Hydrol. Process., 1459, 1448-1459, doi:10.1002/hyp, 2007.

Collins, A. L., McGonigle, D. F., Evans, R., Zhang, Y., Duethmann, D., and Gooday, R.: Emerging priorities in the management of diffuse pollution at catchment scale, Int. J. River Basin Manag., 7, 179-186, 2009.

Collins, A. L., Walling, D. E., McMellin, G. K., Zhang, Y., Gray, J., McGonigle, D., and Cherrington, R.: A preliminary investigation of the efficacy of riparian fencing schemes for reducing contributions from eroding channel banks to the siltation of salmonid spawning gravels across the south west UK, J. Environ. Manage., 91, 1341-1349, doi:10.1016/j.jenvman.2010.02.015, 2010.

Defra: Water Framework Directive implementation in England and Wales: new and updated standards to protect the water environment, May, 41 pp., available at: www.gov.uk/government/ publications, 2014

Edina Digimap: River Rother catchment: $50^{\circ} 59^{\prime} 8.31^{\prime \prime} \mathrm{N}$, $0^{\circ} 44^{\prime} 21.82^{\prime \prime} \mathrm{W}$, elevation $31 \mathrm{M}$, Univ. Edinburgh, available at: http://digimap.edina.ac.uk/digimap/home, 2014.

Environment Agency: Catchment Data Explorer: Western Rother, available at: http://environment.data.gov.uk/catchment-planning/ OperationalCatchment/3533, last access: 2 December 2016.

Evans, R.: Soils at risk of accelerated erosion in England and Wales, Soil Use Manage., 6, 125-131, doi:10.1111/j.14752743.1990.tb00821.x, 1990.

Evans, R.: Runoff and soil erosion in arable Britain: changes in perception and policy since 1945, Environ. Sci. Policy, 13, 141-149, doi:10.1016/j.envsci.2010.01.001, 2010.

Foster, I. D. L., Lees, J. A., Owens, P. N., and Walling, D. E.: Mineral magnetic characterization of sediment sources from an analysis of lake and floodplain sediments in the catchments of the Old Mill reservoir and Slapton Ley, South Devon, UK, Earth Surf. Proc. Land., 23, 685-703, doi:10.1002/(SICI)10969837(199808)23:8<685::AID-ESP873>3.0.CO;2-8, 1998.
Met Office: Midhurst Climate, available at: http://www.metoffice. gov.uk/public/weather/climate/gcp6p1zhh, 2014.

Naden, P. S., Murphy, J. F., Old, G. H., Newman, J., Scarlett, P., Harman, M., Duerdoth, C. P., Hawczak, A., Pretty, J. L., Arnold, A., Laizé, C., Hornby, D. D., Collins, A. L., Sear, D. A., and Jones, J. I.: Understanding the controls on deposited fine sediment in the streams of agricultural catchments, Sci. Total Environ., 547, 366-381, doi:10.1016/j.scitotenv.2015.12.079, 2016.

Official Journal of the European Communities: Directive 2000/60/EC of the European Parliament and of the Council of 23 October 2000; establishing a framework for Community action in the field of water policy, 2000.

Phillips, J. M., Russell, M. A., and Walling, D. E.: Timeintegrated sampling of fluvial suspended sediment: A simple methodology for small catchments, Hydrol. Process., 14, 25892602, doi:10.1002/1099-1085(20001015)14:14<2589::AIDHYP94>3.0.CO;2-D, 2000.

Pittam, N. J., Foster, I. D. L., and Mighall, T. M.: An integrated lakecatchment approach for determining sediment source changes at Aqualate Mere, Central England, J. Paleolimnol., 42, 215-232, doi:10.1007/s10933-008-9272-9, 2008.

Pulley, S., Foster, I., and Antunes, P.: The uncertainties associated with sediment fingerprinting suspended and recently deposited fluvial sediment in the Nene river basin, Geomorphology, 228, 303-319, doi:10.1016/j.geomorph.2014.09.016, 2015.

Rose, N. L., Morley, D., Appleby, P. G., Battarbee, R. W., Alliksaar, T., Guilizzoni, P., Jeppesen, E., Korhola, A., and Punning, J. M.: Sediment accumulation rates in European lakes since AD 1850: Trends, reference conditions and exceedence, J. Paleolimnol., 45, 447-468, doi:10.1007/s10933-010-9424-6, 2010.

Sear, D. A.: Fine Sediment Accumulation in the River Rother, West Sussex, Environ. Agency, 1996.

South Downs National Park Authority: Land Use in the River Rother Catchment, Ord. Surv. 100050083, 2015.

Walling, D. E., Collins, A. L., and Stroud, R. W.: Tracing suspended sediment and particulate phosphorus sources in catchments, J. Hydrol., 350, 274-289, doi:10.1016/j.jhydrol.2007.10.047, 2008. 